Covered in: Web of Science (WOS); EBSCO; ERIH+; Google Scholar; Index Copernicus; Ideas RePeC; Econpapers; Socionet; CEEOL; Ulrich ProQuest; Cabell, Journalseek; Scipio; Philpapers; SHERPA/RoMEO repositories; KVK; WorldCat; CrossRef; CrossCheck

2020, Volume 11, Issue 3, pages: 257-268 | https://doi.org/10.18662/po/11.3/212

\section{Challengers to Conceptual Understanding of Sustainable Development Regarding Decentralization of Power and Responsibility in the Conditions of the Postmodern Society}

\author{
Myroslav KRYSHTANOVYCH ${ }^{1}$, \\ Rostyslav DZANYY2, \\ Elzara TOPALOVA 3 , \\ Ilmira TOKHTAROVA, \\ Nataliya PIROZHENKO ${ }^{5}$
}

\footnotetext{
${ }^{1}$ Lviv Polytechnic National University, Lviv, Ukraine mf0077@ukr.net ${ }^{2}$ Lviv Polytechnic National University, Lviv, Ukraine rostidz@i.ua

${ }^{3}$ Kherson National Technical University, Kherson, Ukraine elzarat@i.ua

${ }^{4}$ Kherson National Technical University, Kherson, Ukraine ilmira2003@i.ua

${ }^{5}$ Odessa Regional Institute for Public Administration, Odessa, Ukraine tnatapirzh@i.ua
}

Abstract: Globalization processes and crisis tendencies of modern society prompt them to be solved primarily in the framework of management, top-level management, and government management. Reforming in most developed countries goes in two directions: delegation of authority to places, decentralization of power and, accordingly, strengthening the responsibility of local authorities for decisions made, in accordance with the accumulation of experience and competencies, will certainly contribute to the sustainable development of territories. The idea of decentralization of power is quite young, since almost until the twentieth century, federalized (decentralized) states were perceived as weak, which corresponded to reality in the conditions of constant wars of conquest. As historical examples come to mind two remarkable events that occurred at different times in different countries, and, accordingly, had different consequences. The vital activity of people in society, the way of their self-affirmation and development in the world, socio-historical practice. Since the socio-historical practice of people is based on their activities, in which there is not only a rapid transformation of the natural and social conditions of life of people, but also of themselves. The basis of socio-historical practice of people is world experience, embodying various contacts of people with nature and with each other in the process of various activities, where the leading role belongs to management and self-government. With the development of the economy and the growth of individual demand, due to the increasing complexity of social contacts, society was faced with an increase in social contradictions.

Keywords: sustainable; decentralization; power; postmodern; society.

How to cite: Kryshtanovych, M., Dzanyy, R., Topalova, E., Tokhtarova, I., \& Pirozhenko, N. (2020). Challengers to Conceptual Understanding of Sustainable Development Regarding Decentralization of Power and Responsibility in the Conditions of the Postmodern Society. Postmodern Openings, 11(3), 257-268. https://doi.org/10.18662/po/11.3/212 


\section{Introduction}

Thanks to the unity of lands, thoughts, society and citizens, Chinese civilization were able to withstand the barbarian invasions. Confucius, as a statesman, is concerned about the state of affairs of the then society, the disobedience of citizens to the emperor and, accordingly, the weakness of civilization before an external enemy and the possible prospect of its destruction, was able to build such an ideological program that cemented the nation for centuries, helped to withstand the enemy and left magnificent works. The following example is the opposite of the result. In the external threat, under the Mongol-Tatar invasion, the lands of Kyiv Rys were divided, they could not resist and the civilization of Kyiv Rys fell, for a long time the Ukrainian territories developed as part of other states without their own statehood.

So, the thesis "in unity is power", which was the fundamental justification of centralized power, was justified, but at a certain historical time. The modern world has completely different development trends. Thus, population mobility and poor leadership in a certain region can lead to population outflow, decline of certain territories and "overload" of successful regions. So, certain territories, regions and even countries may fall under the pressure of external factors that are more threatening today than external factors. Therefore, the responsibility of local authorities, the responsibility of local self-government is becoming of great relevance in our time (Hall, 1992).

The existence of self-government is determined by the need for joint activities of people and is a certain branch of public relations, in the sphere of which the local community independently solves local issues at its discretion. This area includes a wide range of problems that determine the life of society as a whole, and self-government is not only a system of relations that arises in connection with the solution of these problems, not only as an independent management of local affairs, taking into account the influence of many objective and subjective factors, but also as a power local community, where "power acts as an opportunity to achieve completeness and completeness".

As you know, democracy means the power of the people. That is, the people really should be the main and only subject of power during the democratic system. And in modern democracy, "the legitimacy of power is based on the people, but the image of popular sovereignty is associated with the image of an empty place that cannot be occupied, since people who use 
power in society can never claim to be appropriated" (Walsham, 1993). Apparently, therefore, the basic requirement of democracy requires existence of the legal principle of "separation of powers". In order for this principle to apply not only to legislative, executive, supervisory and judicial authorities, but also to all members of society. However, in public practice, "separation of powers appears as some kind of ephemeral theoretical problem". With such an attractive "ephemeral world" the problem of the "insolubility of democracy" inevitably arises: on the one hand, power comes from the people, and on the other, it is distributed between the "branches of power", among which the leading role belongs to the executive bodies of state power (Zhao, 1987).

\section{The main problems of decentralization of power in a postmodern society}

Excessive concentration of power, as shown by social historical experience, including modern states, repels most members of society from social and other responsibility for the state of affairs, causing mass apathy, makes the life of the local community dependent on government in a postmodern society. Any form of dependence limits the freedom of activity of both a person and the local community as a whole and leads to a loss of responsibility. Only the real existence of personal freedom is capable of influencing the emergence of a sense of personal responsibility, without which there can be no full-fledged labor activity, and without which selfmanagement is impossible. Thus, in order to extend responsibility for the state of affairs in society to each of its members, it is necessary to make it general, necessary (Meyer, 2011).

Such a look at the concept of social structure is ideal in the context that power relations are too broad, they cover many areas of government associated with the inevitability of the existence of administrative hierarchical structures, various degrees of responsibility and freedom of activity, and therefore it cannot exist in a "pure" form. Like any mental construction, this concept is abstract, it reflects a certain state. But it is also concrete, because if you provide its inherent dynamism and reveal real internal contradictions, it turns out that it certainly provides for the establishment in all spheres of activity of a more or less equal deposit relationship, in which responsibility is the most important function of human activity, and power is a function responsibility. In a truly democratic society, power in its manifestations cannot and should not exist only as a potential or actual form of coercion. 
The appearance of various interdependencies of man is a certain product of human activity, a distorted form of expression of the essential forces of man. Therefore, the problem of overcoming alienation appears at the same time as a process of returning power to a person and is solved by a person's appropriation of his own essence, the elimination of various relations of unilateral dependence.

Human activities and power in a postmodern society should be carried out through delegation of authority from the bottom up and full accountability of the upper levels to the lower. "Securing the state and those under its control from abuse of power," "consists, on the one hand, primarily in hierarchy and responsibility, on the other, in the first communities ... and in some cases insufficient control from above complemented by control from below" (Golinskaya, 2019).

The absence of a rigid centralized connection between the autonomous and self-sufficient parts of the whole in the conditions of a postmodern society, to which we include the local community with its resources, opens up for them the possibility of internal self-development, makes them more "flexible" and resistant to changes.

Such possibilities are suppressed from above. Moreover, the development of modern society is fully oriented to Western standards and Ukraine is no exception. "Domestic theorists and practitioners should have set themselves the task of passing through the characteristic method of producing social life for our country and the content of social determination, as well as the task of taking into account the natural separation of powers system for our country, but they continue to borrow Western schemes of state building and, moreover, insist on their practical implementation ", in addition to the fact that at each next stage of social development, the authorities objectively solve the same problem - the problem of getting out of tradition into civilization (Vilizhinsky, 2020).

The mechanical transfer of the culture of development of European civilization to the political space of Ukraine always ended with bureaucratic profanity. The architects of "restructuring", creating the "myth of the West", tried to integrate Ukraine into the European space. Modern general integration is becoming a paradoxical tool for the final disintegration and destruction of our state. In society, there is a dangerous process of manipulating the consciousness of the people and planting alien cultural values. The frank and massive manipulation of Western values only reinforces apathy in the relationship of man to man, to his being. In this regard, human activity becomes aggressive in nature, and "society acts as an 
object, torn from a state of universal connection of phenomena, as an object" in itself" (Polyakova, 2019).

It is known that the rule of real progress is that the state should limit the internal moral world of a person as little as possible, providing it with free spiritual development. At its core, power has been given to man in order to "on the one hand be a puppet of objective necessity, but on the other hand, it does not give her absolute permissiveness". Man must return to his original essence: to organize his being according to the laws of the cosmic organization of matter. In this case, she will discover for herself and others "the paths to other essential, spiritually rich forms of being" (Kyosse, 2020).

All this requires higher standards for the person-subject, which must accurately capture the essence of what is happening in public life, consisting of the collective intelligence of the local community as a whole, and its constituent people. The more developed the collective intelligence of society in quantitative and, of course, in qualitative terms, its desire for selfdevelopment, the more effective are the actions of management entities: society as a whole, the state, government, each person as an active subject of social relations.

The personal power of a person-subject is not just the ability and the possibility of mastering the power flowing through a person and the world around him, but, first of all, and this is most important, the controllability of its purpose with the goal of creative development and improvement of its being and its environment.

Therefore, self-government is a special type of human activity that not only comes down to achieving the reform goals of the state, but also is a means of maintaining its integrity, optimal functioning and development (Maples, 2007).

Domestic social experience indicates the need for democratization of social development, where the most important function of managing society is the most complete inclusion in the management of the entire population. The main objective of this function is to create a space for self-development, self-expression of the essential forces of each person individually on the basis of self-government and self-regulation.

In addition, this function forms a sense of common interest and responsibility of each person and the local community; they get used to not only decide their own affairs, but also to monitor the progress of social development. Power becomes common: society finds the opportunity to govern itself independently, and the state acts in the minds of the people as the highest principle of justice. 
During the centuries-old history of mankind, power has always influenced the lives of people. It is a type of problem of the power circle, the resource issue of the need to establish and the "content" of power, the issue of influence to the power relations has always been of interest to people.

\section{The basic principles of high quality state power for postmodern society}

At all stages of public life in the conditions of a postmodern society, occurs the disintegration of power structures. A feature of the current state of power is that there are not only changes in power relations, but qualitative, significant transformations.

One of the radical changes in power is the transition from quantitative to qualitative changes. And therefore, modern postmodern society implies the emergence of "high-quality power", which is based on the following principles (Groysman, 2019).

1. The effectiveness of power. The properties of high-quality power are efficiency - the ability to achieve the goal at the lowest cost, the ability not only to overcome crisis situations, but also to prevent their occurrence. In addition, knowledge allows to possess resources such as violence and wealth.

However, the problem of the effectiveness of power is unresolved and quite debatable. An abstract expression of the effectiveness of power lies in the possibility of complete manipulation of the consciousness of people. In order to establish "disciplinary power," the decisive role was played by people's desire for efficiency. It is the focus of actions on efficiency, the desire to get the maximum result in a certain period of time with a minimum amount of effort, which contributes to the emergence of disciplinary power, the essential characteristic of which is the ability to form law-abiding citizens.

In order to achieve his goals, a person is ready to adhere to strict rules and attitudes. According to Cherkasov (2019), the desire for efficiency, the desire to be "successful" becomes a sufficient basis for establishing a "disciplinary authority" (Cherkasov, 2019).

2. Domineering space. Discipline as a way of creating civic unity is aimed at organizing space and sharing time. The individual's place is clearly defined; special attention is paid to ensure that the allotted place is functional. All movements, gestures, human operations must be subordinated to the principle of greatest efficiency, which is expressed not 
only in the efficient distribution of time, but also in the desire to "run out of time". Every minute should be scheduled and distributed.

The rapid processes of power transformation lead to various configurations of space and time. In modern high-tech societies, there is a "compression of space and time". This phenomenon is observed in the fact that any points in space are becoming more accessible and, accordingly, mastered. The time spent on reaching and mastering various new phenomena is also rapidly decreasing. And therefore, the speed of information transfer is growing (Trebin, 2018).

The essence of the processes of compression of spatio-temporal characteristics is social stratification. In the modern world, a new, important sign of social stratification is emerging - this is social mobility, which involves "freedom of movement" (Vorona, 2019).

3. Unlimited power by the territory. Studying the modern development of society, Ownership of capital, money that can be invested in production, projects, and company activities, allow the owner of the company to be extremely mobile, divorced from space. There is no longer any need, for the approval and "sending" of one's own power, to organize space in a certain way. The conditions for capital investment are: territory (physical space), resources, developed infrastructure, people's productivity. The specificity of the situation is that the "investment infusion" is not aimed at improving the conditions for production, on the contrary, capital is invested in existing, most favorable conditions. Kozak (2019), characterizing this state of affairs, concludes that there is an unprecedented separation of power from duties and obligations, not only to employees, but to those who will subsequently work and live in these territories.

Power does not bother to build a total control system, it no longer needs total control modes. Physical space becomes plastic and pliable thanks to such power resources as knowledge embodied in wealth, technology and so on (Muzyka-Stefanchuk, 2020).

Distance was considered as an objective, "undeniable" characteristic of physical space in those days when there were no high-speed means of transportation and information transfer methods. So, the current state of affairs is characterized by the fact that spatial characteristics are "not a physical given", but a product of social development. Speed determines not only distance, but also acts as a condition for social mobility.

Kuybida (2020) points to the emergence of completely new, qualitatively different properties of space. In the organized space, according to engineering and design a calculation, the artificial prevails over the natural, 
technical means supplant "direct human participation", rationalized replaces public.

The change in spatial characteristics creates the conditions under which all forms of social interaction, including power ones, have changed. A feature of the interaction of "dominant and subordinate" was the exclusion of direct communication. The need for various forms of control has practically disappeared, the government has ceased to establish rules and demand their unquestioning implementation. A "deterritization of power" took place, which allowed finding new resources for subordination; the most effective is risk. "The feeling of risk is a new guarantee of submission, all the more a reliable guarantee, since in conditions when people are faced with the need to cope with their problems on their own, unfortunately, insufficient to establish control over the current situation, it is difficult to imagine the possibility of thoughts in them coming up changes in their position" (Pigul, 2019).

Power, which can be expressed as a collection of symbols, avoids the need to take responsibility, intervene in the solution of various crises that shake society. Behind the backs of state formations in a post-modern society there is a territorially, newly formed power, the presence of which is manifested in such concepts as the global financial crisis, world markets, global investors.

4. The functioning of modern power. Since the formation of the ancient states, the authorities strove to demonstrate their own power and strength. The forms of demonstration of power were: public executions, departures of government officials, the construction of palaces and the like. The authorities demonstrated their greatness, emphasizing their own awareness, ubiquity and effectiveness.

In the current globalization processes, power manifests itself in a high-speed mode of existence, which is mobile and directs its efforts not to approve its own directives, but to deprive others of the ability to make important organizational decisions. The paradox of power relations lies in the fact that it does not assume responsibility for making decisions, it refers to the existence of depersonalized forces that have a decisive and, as a rule, difficultly predicted impact on the current state of affairs. The demonstration is supplanted by the desire of the authorities to be "opaque" (Kolyshko, 2019), inaccessible to the majority. The authorities do not set the goal of self-assertion through the establishment of order, through the organization, establishment of control and discipline. The resource of power is uncertainty, constant variability, unpredictability of the social world (Kornienko, 2017). 
In conditions of active change, a person is forced to constantly adopt new strategies for survival. Mobility, as a characteristic feature of modern life, for most people turns into instability, expressed in the fact that a person repeatedly changes his profession, family, and values. For example, career success is also associated with the ability to quit, abandon the unpromising and take on a new one that provides the opportunity to achieve your goals at the moment of being. According to the understanding of success, a specialist model is also being formed. A person does not seek to obtain fundamental knowledge; she cannot afford to spend more time on the development of some knowledge, or on the development of some skills.

Paradoxically, at this point in time in a postmodern society, a person is trying to possess information to accelerate his own mobility. Power does not impose order, it does not force discipline, and it leaves a person in a situation of constant choice. The types of manifestations of the activity of modern power are not directives and orders, but the formation of symbols, simulacra (copies of which there is no original), demonstrating a successful life, which is expressed in the ability to "own the world" (Malinovsky, 2015).

Thus, the unlimited power (including territory) in a postmodern society also manifests itself in the fact that officials have privileges that enable them not to be responsible for the space (physical and social) in which they exercise their powers. A special manifestation of modern power relations is that most people deprived of "freedom of movement", having one place of residence, also do not seek to transform, improve their own lives within the existing space. For them, attachment to a place, "settledness" is considered as a condition that must be overcome. It is necessary to move to where there is a dignified, comfortable life, and not to turn your life into these conditions.

\section{Conclusions}

Thus, in a postmodern society, power shifts to a policy of flexible management, it no longer creates a panopticon, on the contrary, is now the object of observation and close attention to the lives of people in power. In ancient times, Confucius proclaimed the thesis that the emperor should be an example for the people - as the emperor, so is the person. The modern form of government creates symbols of a prosperous life, becomes an example for the majority. Unfortunately, one of the most important traits inherent in power and perceived by the majority is the unwillingness to take responsibility. In everyday life and at the level of government decisionmaking, people increasingly refer to the fact that in the proposed 
circumstances, they are not responsible for the consequences of their actions.

Refusal of responsibility, unwillingness to make decisions and organize the conditions of their lives, or the lives of entire peoples, in the context of globalization processes can lead to irreversible devastating consequences.

Thus, the essence of power in today's globalized world manifests itself in completely different forms and sets different goals and objectives than in previous times. First, power has become more effective, rapidly evolving knowledge, which acts as the main tool of power, which allows on the one hand, to democratize various forms of government and methods of organization, and on the other hand, to establish total forms of dependence. Choosing the optimal solutions, guided by the special knowledge of the person of his own free will, on the basis of his decisions becomes a "onedimensional", programmed individual. Behavior that does not meet rational norms is regarded as a deviation from the norm. The processes of humanization and democratization of power become the basis for the enslavement of people, allowing not just to govern, but to "make obedient bodies." Secondly, the traditional tasks and functions of power, is to establish control, order based on certain norms, are replaced by a complete renunciation of control, power is eliminated (separated from the effects of physical and social order) from the need to solve important social problems, giving people complete freedom choices in finding survival strategies. Individualism and freedom of choice are invariably associated with risk, which becomes the main function of management. Third, the processes of depersonalization of both objects and subjects of power are intensifying, ultimately leading to a lack of responsibility for the chosen and implemented management strategies.

\section{References}

Cherkasov, A. (2019). Detsentralizatsiya vlady: uroky pol's'koyi movy dlya Ukrayiny [Decentralization of power: Polish lessons for Ukraine]. State building, 12, 111.

Golinskaya, A. V. (2019). Voluntary association of territorial communities resistance factors, objective positions and advantages. https://oridu-nadu.livejournal

Groysman, V. (2019). The structural and functional role of decentralization of power in the processes of the formation of civil society. The effectiveness of public administration, 44, 221-229. 
Hall, M. (1992). The Decentralization of Development- Impact on Power, Priorities, Faculty Perceptions. Teachers College Record. 93(3), 569-582. https://apps.webofknowledge.com/full record.do?product=WOS\&search mode $=$ GeneralSearch\&qid $=5 \& S I D=F 4 j 1 \mathrm{Tm} 32 \mathrm{XX} 8 \mathrm{z} 3 \mathrm{AZRzj}$ P\&page $=4$ $\underline{\& \mathrm{doc}}=36 \&$ cacheurlFromRightClick $=$ no

Kolyshko, G. A. (2019). Detsentralizatsiya publichnoyi vlady: istoriya ta suchasni tendentsiyi rozvytku [Decentralization of public authority: history and modern development trends]. Bulletin of KNU, 27, 201-205.

Kornienko, M. (2017). Mistseva vlada ta "uryadova vertykal"" [Local government and the "government vertical"]. Local government, $3 / 4$ (5), 37-43.

Kozak, V. I. (2019). Analiz naukovoyi spadshchyny u vyznachenni detsentralizatsiya yak yavyshche [Analysis of scientific heritage in the definition decentralization as a phenomenon]. State building, 1. http://www.kbuapa.kharkov.ua/ebook/db/2017-1/doc/1/04.pdf

Kuybida, V. S. (2020). Principles and methods of activity of local authorities: Monograph. IAPM.

Kyosse, L. M. (2020). Public opinion as a component of legitimate political power. Actual problems of politics, 56, 227-233.

Malinovsky, V. Y. (2015) Slovnyk terminiv ta ponyat' derzhavnoho upravlinnya. 2-e vyd. i vypravyty tse [Glossary of terms and concepts of public administration. 2nd ed. and fix it]. Center for the Promotion of Institutions. state development service, 13, 51-56.

Maples, W. (2007). The politics of decentralization: Forests, power and people. Environmental Politics, 16(1), 169-171.

https://apps.webofknowledge.com/full_record.do?product=WOS\&search mode $=$ GeneralSearch\&qid $=19 \& S I D=F 4 j 1$ Tm32XX8z3AZRzjP\&page $=1$ $\underline{\& d o c}=1$

Meyer, M. (2011). The Decentralizatoin of Political-Power. After Perestroika: Democracy In The Soviet Union, 13, 39-49.

Muzyka-Stefanchuk, O. (2020). Decentralization Of Power In Ukraine And Europe: Security And Finance Issues. Financial And Credit Activity-Problems Of Theory And Practice, 1(32), 351-359. https://apps.webofknowledge.com/full_record.do?product=WOS\&search _mode $=$ GeneralSearch\&qid $=21 \& S I D=F 4 j 1 T m 32 X X 8 z 3$ AZRzjP\&page $=1$ $\underline{\& \operatorname{doc}=2}$

Pigul, N. G. (2019). Foreign experience in carrying out decentralization reforms. Global and national problems of the economy, 9, 684-688.

Polyakova, S. V. (2019). Detsentralizatsiya vlady v Ukrayini: problemy ob"yednanykh hromad [Decentralization of power in Ukraine: problems united communities]. Electronic scientific publication: Economics and society, 13, 1033-1039. 
Trebin, M. P. (2018). Suchasnyy stan hromadyans'koho suspil'stva v Ukrayini: problemy ta perspektyvy [The current state of civil society in Ukraine: problems and prospects]. Ukrainian society, 4 (47), 161-174.

Vilizhinsky, V. (2020). Sutnist' sil's'koyi terytorial'noyi hromady ta yiyi rol' u formuvanni ta rozvytku tradytsiy natsional'noho upravlinnya. [The essence of the rural territorial community and its role in the formation and development of national management traditions]. Actual problems of public administration, 2,143-146.

Vorona, P. V. (2019). Features of the development of local self-government in Japan in the process of decentralization of power. Actualproblems of public administration, 2, 277-285.

Walsham, G. (1993). Decentralization Of Is In Developing-Countries - Power To The People. Journal of Information Technology, 8(2), 74-81. https://www.doi.org/10.1057/jit.1993.11

Zhao, B. (1987). Horizontal And Vertical Decentralization Of Power In China Political-Structure. Joumal: Argument, 29(5), 698-707. https://apps.webofknowledge.com/full record.do?product=WOS\&search mode $=$ GeneralSearch\&qid $=5 \& S I D=F 4 j 1 T m 32 X X 8 z 3$ AZRzjP\&page $=4$ $\underline{\& \mathrm{doc}=40 \& \text { cacheurlFromRightClick }=\text { no }}$ 